\title{
REVIEW
}

\section{Approaches to achieve high grain yield and high resource use efficiency in rice}

\author{
Jianchang YANG (凶) \\ Jiangsu Key Laboratory of Crop Genetics and Physiology/Co-Innovation Center for Modern Production Technology of Grain Crops, \\ Yangzhou University, Yangzhou 225009, China
}

\begin{abstract}
This article discusses approaches to simultaneously increase grain yield and resource use efficiency in rice. Breeding nitrogen efficient cultivars without sacrificing rice yield potential, improving grain fill in laterflowering inferior spikelets and enhancing harvest index are three important approaches to achieving the dual goal of high grain yield and high resource use efficiency. Deeper root distribution and higher leaf photosynthetic $\mathrm{N}$ use efficiency at lower $\mathrm{N}$ rates could be used as selection criteria to develop N-efficient cultivars. Enhancing sink activity through increasing sugar-spikelet ratio at the heading time and enhancing the conversion efficiency from sucrose to starch though increasing the ratio of abscisic acid to ethylene in grains during grain fill could effectively improve grain fill in inferior spikelets. Several practices, such as post-anthesis controlled soil drying, an alternate wetting and moderate soil drying regime during the whole growing season, and non-flooded straw mulching cultivation, could substantially increase grain yield and water use efficiency, mainly via enhanced remobilization of stored carbon from vegetative tissues to grains and improved harvest index. Further research is needed to understand synergistic interaction between water and $\mathrm{N}$ on crop and soil and the mechanism underlying high resource use efficiency in high-yielding rice.
\end{abstract}

Keywords rice, nitrogen-efficient cultivar, grain fill, harvest index, nitrogen use efficiency, water use efficiency

Received February 25, 2015; accepted May 20, 2015

Correspondence: jcyang@yzu.edu.cn

\section{Introduction}

Rice (Oryza sativa) is one of the most important food crops in the world, providing $35 \%-60 \%$ of the dietary calories consumed by approximately 3 billion people ${ }^{[1]}$. Rice in China is the staple food for more than $65 \%$ of the population $^{[2,3]}$. To meet the population growth, China has paid great attention to increase rice yield, from $2.1 \mathrm{t} \cdot \mathrm{hm}^{-2}$ in 1950 to $6.5 \mathrm{t} \cdot \mathrm{hm}^{-2}$ in $2012^{[4]}$. The national average rice yield was $6.7 \mathrm{t} \cdot \mathrm{hm}^{-2}$ in 2013 , which was $56 \%$ higher than the world average $\left(4.3 \mathrm{t} \cdot \mathrm{hm}^{-2}\right)$. These great advances in rice production in China have been important for increasing food supply and security. However, such advances result partly from high inputs of water and chemical fertilizers especially over-use of nitrogen fertilizer. In China today the average $\mathrm{N}$ application rate in rice is about $180 \mathrm{~kg} \cdot \mathrm{hm}^{-2}$, which is $75 \%$ above the world average ${ }^{[2,3]}$. Excessive fertilization with $\mathrm{N}$ results in decreased $\mathrm{N}$ use efficiency (NUE). It is reported that recovery efficiency of $\mathrm{N}$ fertilizer (the percentage of fertilizer $\mathrm{N}$ recovered in aboveground plant biomass at the end of the cropping season) in China is only 30\%-35\%, which is 15\%-20\% below that in other major rice growing countries $^{[3,5]}$. In the high yielding area of Taihu Lake, the average $\mathrm{N}$ input is $300 \mathrm{~kg} \cdot \mathrm{hm}^{-2}$, and the average agronomic $\mathrm{N}$ use efficiency $\left(\mathrm{AE}_{\mathrm{N}}\right.$, increase in grain yield per kilogram $\mathrm{N}$ applied) is only $12 \mathrm{~kg} \cdot(\mathrm{kg} \mathrm{N})^{-1}$, less than half of that in the developed countries ${ }^{[6,7]}$. Excessive $\mathrm{N}$ input not only results in lodging, severe occurrences of diseases and insects, and poor grain quality in rice, but also pollutes the environment ${ }^{[2,8,9]}$. Moreover, in spite of a continuous increase in fertilizer input to rice production in China, the rice yield increase has slowed since the 1990s, as reflected by the sharp drop in the annual yield increase rate from $3.7 \%$ in the $1980 \mathrm{~s}$ to $0.9 \%$ in the $1990 \mathrm{~s}^{[10]}$, and $0.5 \%$ between 2000 and $2007^{[11]}$.

Water shortage and low water use efficiency (WUE) are 
two other problems affecting rice production in China. Water resource per capita in China is $23 \mathrm{ML}$, only a quarter of the world average, and $60 \%-70 \%$ of this is used agriculture. Rice production is the biggest water user, and consumes about $60 \%-70 \%$ of the total irrigation water in agriculture $^{[12]}$. During the past 20 years, the annual water shortage for irrigation in China's agriculture was $3 \times 10^{12} \mathrm{~L}$, and drought occurred over $2.0 \times 10^{8}-2.6 \times$ $10^{8} \mathrm{hm}^{2}$. Even in the southeast of China, which is usually considered as a water-rich area, $1.6 \times 10^{6}-2.0 \times 10^{6} \mathrm{hm}^{2}$ of rice suffered seriously from seasonal drought ${ }^{[13,14]}$. Furthermore, WUE for rice irrigation (grain yield over amount of irrigation water) is rather low in China, where irrigation water consumption is $30 \%-40 \%$ higher, while WUE is $40 \%-50 \%$ lower, than in the United States of America under similar seasonal rainfall conditions ${ }^{[15]}$. Low resource use efficiency has been a major factor restricting sustainable agricultural development in China.

With the continuing population growth and economic development in China, food consumption will continue to increase. It is estimated that, by the year 2025, China needs to produce about $20 \%$ more rice than is currently produced to meet the food needs of a growing population ${ }^{[2,3]}$. The questions are whether continuous increases in crop yield can be sustained by simultaneous increases in inputs of water and fertilizer and resource use efficiency. These are contentious issues of agricultural science and remain unresolved $^{[16,17]}$. The developed countries usually adopt the principle of giving priority to environmental protection. However, simultaneous increase in crop yield and resource use efficiency is the only option in China due to its higher population relative to availability of land and other resources. Therefore, this paper discusses approaches to achieve the dual goal of high yield and high resource use efficiency in rice.

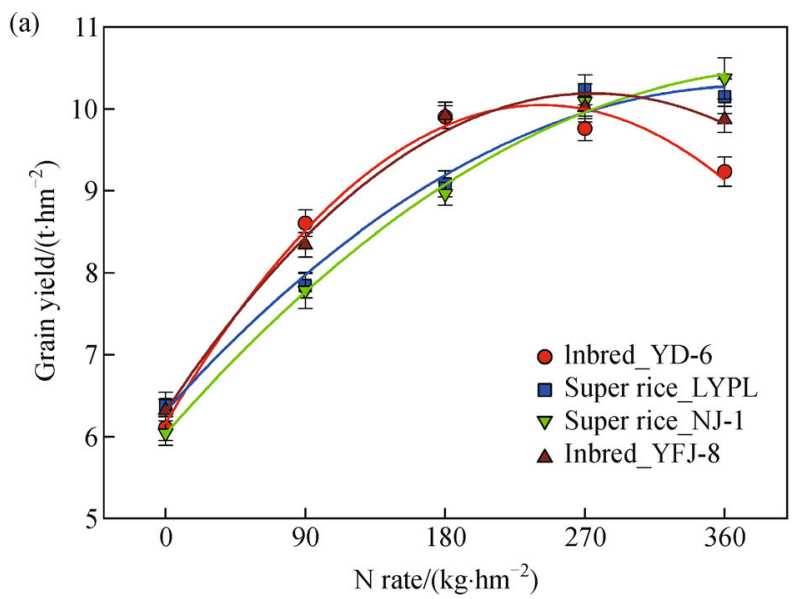

\section{Approaches to achieve high grain yield and high resource use efficiency}

\subsection{Breeding N-efficient rice cultivars without sacrificing grain yield potential}

Development of semi-dwarf rice cultivars during the Green Revolution substantially increased $\mathrm{N}$ fertilizer rates and grain yield because of their lodging resistance at high $\mathrm{N}$ inputs $^{[18-20]}$. To breed rice with higher yield and stronger lodging resistance, progeny with high $\mathrm{N}$ tolerance rather than high $\mathrm{N}$ responsiveness are selected in the breeding nursery under high $\mathrm{N}$ rates ${ }^{[20]}$. As a result, high grain yield must be at the cost of higher amount of $\mathrm{N}$ application, which leads to a lower NUE. The contradiction between high yield and high NUE for a lodging-resistant cultivar was evident in super rice cultivars, which have larger panicle size, greater yield potential, better grain quality, and stronger tolerance to biotic and abiotic stresses than standard cultivars ${ }^{[21,22]}$. When compared to standard cultivars, super rice cultivars produced higher grain yield only at the very high $\mathrm{N}$ rate $\left(360 \mathrm{~kg} \cdot \mathrm{hm}^{-2}\right)$, and both grain yield and $\mathrm{AE}_{\mathrm{N}}$ were comparable when the $\mathrm{N}$ rate was $270 \mathrm{~kg} \cdot \mathrm{hm}^{-2}$, and showed a lower grain yield and lower $\mathrm{AE}_{\mathrm{N}}$ at lower $\mathrm{N}$ rates $\left(90\right.$ and $180 \mathrm{~kg} \cdot \mathrm{hm}^{-2}$ ) (Fig. 1). It is easy to understand that the newly released cultivars have low NUE because of their reduced responsiveness to N. It is hypothesized that the newly released cultivars bred under high $\mathrm{N}$ rates have lower NUE than the older cultivars that were bred under low $\mathrm{N}$ rates, and future breeding nurseries should be limited to lower $\mathrm{N}$ rates such as 120 to $150 \mathrm{~kg} \cdot \mathrm{hm}^{-2[20]}$. However, such a hypothesis needs to be tested in field experiments.

It needs to be determined if it is possible to develop a super rice cultivar with high grain yield and high NUE.

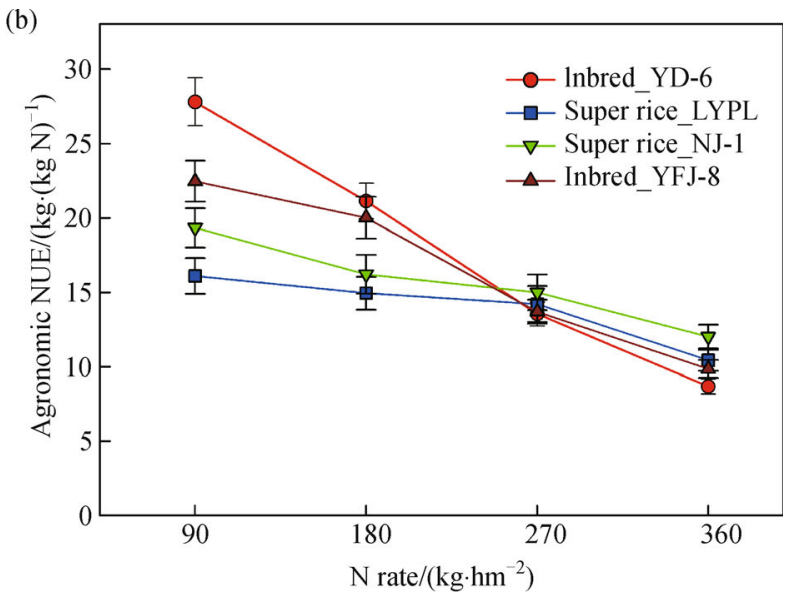

Fig. 1 Responses in grain yield (a) and agronomic nitrogen use efficiency (NUE) (b) of inbred and super rice cultivars to five nitrogen application rates. Vertical bars represent \pm standard error of the mean $(n=4)$ where these exceed the size of the symbol. Data are adapted from Liu et al. ${ }^{[21]}$ and Fan $^{[22]}$. 
Recently it has been observed that there is a large difference in NUE among newly bred super rice cultivars $^{[23]}$. Two super rice cultivars, Huaidao 5 and Lianjing 7, produced higher grain yield, absorbed higher amounts of $\mathrm{N}$ from the soil, and exhibited higher NUE than other super rice cultivars at lower $\mathrm{N}$ rates $(0,100$ or $200 \mathrm{~kg} \cdot \mathrm{hm}^{-2}$ ). The grain yield and NUE of both cultivars were comparable with those of other cultivars at the $\mathrm{N}$ rate of $300 \mathrm{~kg} \cdot \mathrm{hm}^{-2}$. These results suggest that Huaidao 5 and Lianjing 7 are $\mathrm{N}$-efficient cultivars without sacrificing grain yield potential.

Understanding plant traits that are associated with high grain yield and high NUE is crucial for breeding programs aimed at developing N-efficient cultivars. Compared with $\mathrm{N}$-inefficient cultivars, $\mathrm{N}$-efficient cultivars have longer root length, greater root length per volume of soil, root oxidation activity and leaf photosynthetic NUE, and more nonstructural carbohydrate (NSC) remobilization at lower $\mathrm{N}$ rates ${ }^{[23]}$. The agronomic and physiological indices for $\mathrm{N}$-efficient rice cultivars are shown in Table 1. These plant traits, especially deeper root distribution, greater root oxidation activity and higher photosynthetic NUE at lower $\mathrm{N}$ rates, could be used as selection criteria in a breeding program to develop $\mathrm{N}$-efficient rice cultivars that have high yield and high NUE.

\subsection{Improving grain fill in later-flowering inferior spikelets}

In rice and other cereal crops, grain yield can be defined as the product of yield sink capacity and filling efficiency ${ }^{[24]}$. To further increase yield and break the yield ceiling, breeding efforts have expanded yield sink capacity, the maximum size of sink organs to be harvested, mainly by increasing the number of spikelets per panicle ${ }^{[25,26]}$. As a result, cultivars with large panicles or extra-heavy panicle types, namely numerous spikelets per panicle, have become available, such as the New Plant Type of the International Rice Research Institute ${ }^{[27]}$, hybrid rice and super rice in China ${ }^{[28,29]}$. These cultivars, however, frequently do not exhibit their high yield potential due to their poor grain fill, due to slow grain filling rate and many unfilled grains ${ }^{[26,30,31]}$.

The degree and rate of grain fill in rice differs largely with the position of the spikelet in the panicle. In general, earlier-flowering superior spikelets, usually located on apical primary branches, have fast-filling and heavier grains. Later-flowering inferior spikelets, on the other hand, are usually located on proximal secondary branches, and are either sterile or have poor and slow-filling grains that are unsuitable for human consumption ${ }^{[32,33]}$. The problem of slow-filling grain in inferior spikelets is even worse in newly bred super rice cultivars, although they generally show a yield potential of $8 \%-20 \%$ more than other rice cultivars ${ }^{[28,34]}$. For example, 20 super rice cultivars grown in the Lower Yangtze River Basin were found to have an average grain filling proportion and grain weight in inferior spikelets of $21.8 \%$ and $20.1 \%$, respectively, which was lower than those in superior spikelets (Fig. 2). In contrast, these values for 20 standard cultivars were only $8.6 \%$ and $10.9 \%$, respectively. Poor grain fill in inferior spikelets not only reduces yield potential and grain quality, but also decreases WUE and NUE, because inferior spikelets consume much water and nutrients during their development ${ }^{[35-37]}$.

The mechanism underlying poor grain fill in inferior spikelets remains unknown. Recent research has shown

Table 1 Agronomic and physiological indices for N-efficient rice at the $\mathrm{N}$ rate of $200 \mathrm{~kg} \cdot \mathrm{hm}^{-2}$

\begin{tabular}{|c|c|}
\hline Agronomic and physiological traits & Index \\
\hline Grain yield $/\left(\mathrm{t} \cdot \mathrm{hm}^{-2}\right)$ & $\geqslant 9.5$ \\
\hline $\mathrm{N}$ uptake $/\left(\mathrm{kg} \cdot \mathrm{hm}^{-2}\right)$ & $\geqslant 140.0$ \\
\hline Internal $\mathrm{N}$ use efficiency $/\left(\mathrm{kg} \cdot \mathrm{kg}^{-1}\right)$ & $\geqslant 67.0$ \\
\hline Apparent recovery efficiency of $\mathrm{N}$ fertilizer/(\%) & $\geqslant 34.8$ \\
\hline Agronomic $\mathrm{N}$ use efficiency $/\left(\mathrm{kg} \cdot \mathrm{kg}^{-1}\right)$ & $\geqslant 19.5$ \\
\hline Shoot biomass at heading $/\left(\mathrm{t} \cdot \mathrm{hm}^{-2}\right)$ & $9.9-10.3$ \\
\hline Crop growth rate from panicle initiation to maturity $/\left(\mathrm{g} \cdot \mathrm{m}^{-2} \cdot \mathrm{d}^{-1}\right)$ & $\geqslant 14.5$ \\
\hline Specific leaf $\mathrm{N}$ content at heading $/\left(\mathrm{g} \cdot \mathrm{m}^{-2}\right)$ & $2.2-2.3$ \\
\hline Photosynthetic nitrogen use efficiency at heading $/\left(\mu \mathrm{mol} \cdot \mathrm{g}^{-1} \cdot \mathrm{s}^{-1}\right)$ & $\geqslant 10.5$ \\
\hline Root biomass in $10.1-20.0 \mathrm{~cm}$ soil layer at heading $/\left(\mathrm{g} \cdot \mathrm{m}^{-2}\right)$ & $44.5-46.5$ \\
\hline Root length at heading $/\left(\mathrm{km} \cdot \mathrm{m}^{-2}\right)$ & $24.2-26.5$ \\
\hline Root length density at heading $/\left(\mathrm{cm} \cdot \mathrm{cm}^{-3}\right)$ & $12.8-14.2$ \\
\hline Root oxidation activity at heading $/\left(\mu \mathrm{g} \alpha-\mathrm{NA} \cdot \mathrm{g}^{-1} \cdot \mathrm{DWh}^{-1}\right)$ & $450.0-500.0$ \\
\hline Nonstructural carbohydrate in the stem at heading $/\left(\mathrm{g} \cdot \mathrm{m}^{-2}\right)$ & $\geqslant 285.0$ \\
\hline Nonstructural carbohydrate remobilization during grain filling/\% & $57.5-58.5$ \\
\hline
\end{tabular}

Note: Data are adapted from Ju et al. ${ }^{[23]}$. 
that there are two important causes for poor grain fill in inferior spikelets: one is low sink activity (low ATP content, cytokinin concentration, mRNA level, etc.) at the initial grain filling stage, and the other is low ratio of abscisic acid (ABA) to ethylene during the grain filling period $^{[35,38]}$. The low sink activity at the initial grain filling stage can result in a slow division rate of endosperm cells, leading to fewer endosperm cells, smaller sink capacity and grain weight ${ }^{[39,40]}$. Also, a low ratio of ABA to ethylene during grain fill can inhibit activities of the key enzymes involved in sucrose-to-starch conversion in grains and thereby reducing the efficiency of this process, and consequently, lead to poor grain fill ${ }^{[41,42]}$. Further studies showed that super rice has a lower NSC (sugar) to spikelet ratio at heading time, and this ratio was positively and significantly correlated with sink activity at the initial grain filling stage ${ }^{[36,38]}$. Application of potassium at the panicle initiation stage and/or $\mathrm{N}$ fertilizer at the spikelet differentiation stage can significantly increase the sugarspikelet ratio at the heading time through increasing NSC accumulation in stems $0-15$ days before heading, and consequently, increase sink activity at the initial grain filling stage, leading to an improvement in grain fill in inferior spikelets ${ }^{[38,43]}$. Therefore, increasing sugar-spikelet ratio at heading can be considered as an important approach to improving grain fill in inferior spikelets. The technique and mechanism involved in the improvement in grain fill by increasing the sugar-spikelet ratio are summarized in Fig. 3.

An important question is how to increase the ratio of $\mathrm{ABA}$ to ethylene in grains during the grain filling period so that filling of the inferior spikelets can be improved. There are reports showing that an alternate wetting and moderate drying regime (AWMD) can significantly decrease ethylene evolution rate and increase the ratio of $A B A$ to ethylene, and enhance the activities of key enzymes involved in sucrose to starch conversion and expressions of the genes encoding enzymes involved in starch synthesis

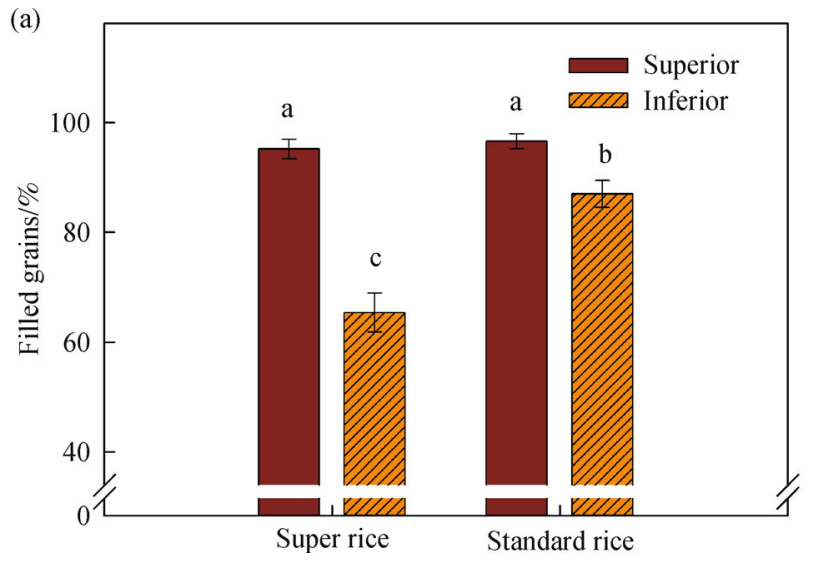

in rice grains ${ }^{[44-46]}$. These processes increase the fill and weight of grain in inferior spikelets, so increasing the ratio of ABA to ethylene in grains by AWMD during grain fill is an important approach, to enhance filling of inferior spikelets. The technique and mechanisms involved in these improvements in grain fill through increasing the ratio of ABA to ethylene are summarized in Fig. 4.

\subsection{Enhancing harvest index to increase grain yield and water productivity}

Global agriculture in the Twenty-First Century faces two major challenges: total food production needs to increase to feed a growing world population, and this increase needs to be accomplished as water resources become increasingly scarce ${ }^{[47]}$. The challenge to produce more food under increasing water scarcity has led to the conclusion that crop water productivity (economic yield over amount of water consumed) needs to increase ${ }^{[48,49]}$. However, the ways to increase water productivity remain unclear ${ }^{[47,49]}$. In cereals and at the crop level, it is proposed that water productivity can be defined as the ratio of grain yield to water transpired $\left(\mathrm{WP}_{\mathrm{T}}\right)^{[47]}$. As the grain yield $(\mathrm{Y})$ is the product of harvest index (HI) and total above-ground biomass (B), that is, $\mathrm{Y}=$ $\mathrm{HI} \times \mathrm{B}$, the $\mathrm{WP}_{\mathrm{T}}$ in rice can be expressed as:

$$
\mathrm{WP}_{\mathrm{T}}=\mathrm{Y} / \mathrm{T}=\mathrm{HI} \times \mathrm{B} / \mathrm{T}
$$

where $\mathrm{WP}_{\mathrm{T}}=$ grain yield per unit water transpired $(\mathrm{kg}$ grain per $\mathrm{kg}$ water), $\mathrm{Y}=$ grain yield $(\mathrm{kg}), \mathrm{T}=$ amount of transpired water $(\mathrm{kg}), \mathrm{HI}=$ harvest index $\left(\mathrm{kg} \cdot \mathrm{kg}^{-1}\right), \mathrm{B}=$ above-ground biomass $(\mathrm{kg})$.

The ratio $\mathrm{B} / \mathrm{T}$ is sometimes known as transpiration efficiency. HI is the grain yield over total above-ground biomass. The grain yield and water productivity can be improved by either increased transpiration efficiency or increased HI. However, the ratio of biomass production over transpiration $(\mathrm{B} / \mathrm{T})$ has been shown to be relatively constant for a given species in given climate ${ }^{[50]}$, and can be

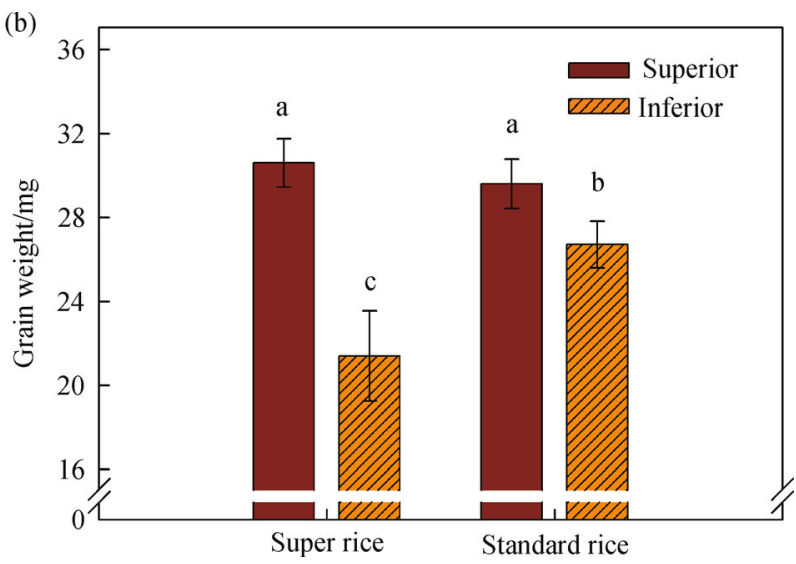

Fig. 2 Mean filled grain percentage (a) and grain weight (b) in superior and inferior spikelets for 20 super rice and 20 standard rice cultivars. Vertical bars represent \pm standard error of the mean $(n=60)$ where these exceed the size of the symbol. Different letters above the column indicate statistical significance at the $P=0.05$ level. Data are adapted from Yang et al. ${ }^{[26]}$, Yang ${ }^{[35]}$ and $\mathrm{Fu}^{[36]}$. 


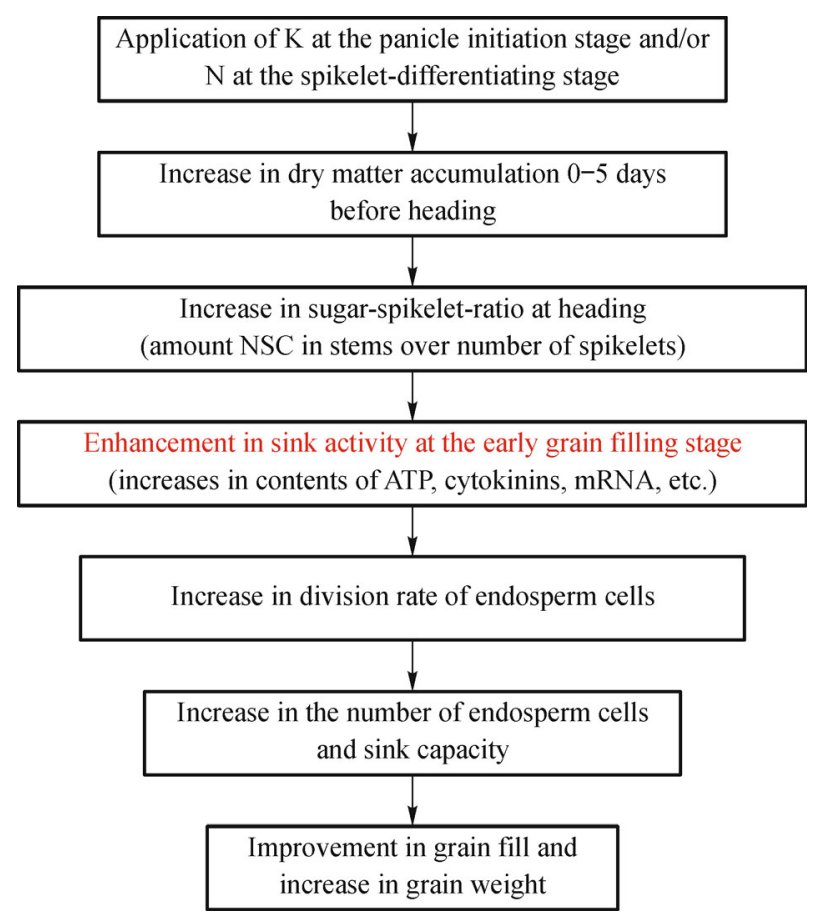

Fig. 3 The technique and mechanism involved in improvement in grain fill in inferior spikelets through increasing sugar-spikelet-ratio at the heading time

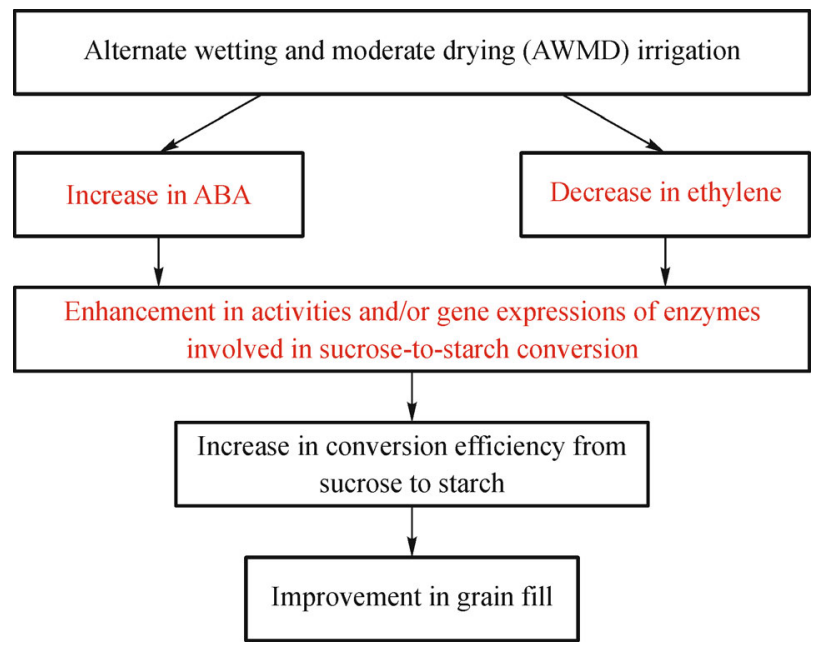

Fig. 4 The technique and mechanism involved in the improvement in grain fill in inferior spikelets through increasing the ratio of abscisic acid (ABA) to ethylene in the grains during the grain filling period

selected for during plant breeding ${ }^{[47]}$. Plant biomass production is linearly coupled with amount of water transpired, and achieving higher WUE often involves a trade-off with lower biomass production ${ }^{[51]}$. In agriculture, many ways of conserving water have been investigated and techniques such as alternate partial irrigation of the root zone, deficit irrigation and drip irrigation have been shown to enhance WUE ${ }^{[51,52]}$. In general, these techniques are a trade-off of lower yield for a higher WUE ${ }^{[51-53]}$.

HI has been shown to be a variable factor in crop production. There are reports that $\mathrm{HI}$ can range from 0.17 to 0.56 in rice ${ }^{[54,55]}$, from 0.31 to 0.51 in wheat ${ }^{[56,57]}$ and from 0.25 to 0.58 in maize ${ }^{[58,59]}$. Increases in grain yield and WUE for a given rice cultivar were mainly achieved through an increase in HI when above-ground biomass was over $18.3 \mathrm{t} \cdot \mathrm{hm}^{-2}$ in the inbred rice cv. Yangdao 6 and over $21.8 \mathrm{t} \cdot \mathrm{hm}^{-2}$ in the hybrid rice cv. Ilyou 084 (Table 2 ). These results demonstrate that increasing HI is an important approach to increasing grain yield and WUE.

$\mathrm{HI}$ increased significantly with the shift from early tall 
Table 2 Above-ground biomass, grain yield, harvest index and water use efficiency of rice*

\begin{tabular}{|c|c|c|c|c|}
\hline Cultivar & Biomass $/\left(\mathrm{t} \cdot \mathrm{hm}^{-2}\right)$ & Grain yield $/\left(\mathrm{t} \cdot \mathrm{hm}^{-2}\right)$ & Harvest index & Water use efficiency $/\left(\mathrm{kg} \cdot \mathrm{m}^{-3}\right)^{\S}$ \\
\hline \multirow[t]{6}{*}{ Yangdao 6} & $18.27 \mathrm{~d}^{\#}$ & $8.77 \mathrm{c}$ & $0.48 \mathrm{e}$ & $0.78 \mathrm{e}$ \\
\hline & $19.05 b$ & $9.04 \mathrm{c}$ & $0.50 \mathrm{~d}$ & $0.81 \mathrm{~d}$ \\
\hline & $18.66 \mathrm{c}$ & $9.52 \mathrm{~b}$ & $0.51 \mathrm{~cd}$ & $0.82 \mathrm{~cd}$ \\
\hline & $18.54 \mathrm{c}$ & $9.64 b$ & $0.52 b c$ & $0.84 \mathrm{c}$ \\
\hline & $18.84 \mathrm{c}$ & $9.98 \mathrm{~b}$ & $0.53 b$ & $0.87 \mathrm{~b}$ \\
\hline & $19.64 \mathrm{a}$ & $10.81 \mathrm{a}$ & $0.55 \mathrm{a}$ & $0.91 \mathrm{a}$ \\
\hline \multirow[t]{4}{*}{ IIyou 084} & $23.18 \mathrm{a}$ & $9.32 \mathrm{c}$ & $0.40 \mathrm{c}$ & $0.77 \mathrm{c}$ \\
\hline & $23.69 \mathrm{a}$ & $9.71 \mathrm{c}$ & $0.41 \mathrm{c}$ & $0.79 \mathrm{c}$ \\
\hline & $21.88 \mathrm{~b}$ & $11.59 \mathrm{~b}$ & $0.53 b$ & $0.83 b$ \\
\hline & $21.86 \mathrm{~b}$ & $12.01 \mathrm{a}$ & $0.55 \mathrm{a}$ & $0.95 \mathrm{a}$ \\
\hline
\end{tabular}

Note: ${ }^{*}$, the field experiments were conducted in Yangzhou and Jiangsu, China in 2008 and 2009. Data are means of the two years and unpublished; $\S$, grain yield over the amount of irrigation water and rainfall; \#, letters after the values indicate least significant difference (LSD) at the $P=0.05$ level within the same column and the same cultivar.

cultivars to dwarf cultivars, and declined slightly from dwarf cultivars to modern super rice cultivars ${ }^{[60]}$, implying that increased HI could be achieved mostly through crop management techniques rather than by rice breeding. Actually, several practices, such as post-anthesis controlled soil drying, a moderate wetting drying regime during the growing season and non-flooded straw mulching cultivation, have been developed and can substantially enhance WUE and increase grain yield in rice, mainly through improved canopy structure, source activity, sink strength and enhanced remobilization of stored carbon from vegetative tissues to grains (Table 3). This work has demonstrated that appropriate crop management holds great promise for enhancing $\mathrm{HI}$ and consequently achieving the dual goal of increasing grain production and saving water $^{[19,61-71]}$.

\section{Concluding remarks}

A simultaneous increase in crop yield and resource use efficiency is essential for China with its large population and growing shortages of land and resources. Breeding Nefficient cultivars without sacrificing rice yield potential, improving grain fill in later-flowering inferior spikelets and enhancing HI are three important approaches to achieve the dual goal of high grain yield and high resource use efficiency in rice. Deeper root distribution, longer root length, greater root length per volume soil, root oxidation activity and leaf photosynthetic NUE, and more NSC remobilization at lower $\mathrm{N}$ rates could be used as selection criteria in the breeding program to develop $\mathrm{N}$-efficient cultivars.

Poor grain fill in inferior spikelets not only limits yield potential, but also decreases resource use efficiency. Enhancing sink activity through an increase in sugarspikelet ratio during heading and increasing the conversion efficiency from sucrose to starch though increasing the ratio of ABA to ethylene in grains during grain fill could effectively improve grain fill in inferior spikelets.

Enhancement in HI would increase WUE without compromising grain yield. Several practices, such as post-anthesis controlled soil drying, alternate wetting and moderate soil drying regime during the whole growing

Table 3 Crop management techniques for increasing harvest index in rice

\begin{tabular}{|c|c|c|c|}
\hline $\begin{array}{l}\text { Crop management } \\
\text { techniques }\end{array}$ & Key points of the techniques & $\begin{array}{l}\text { Main agronomic and physiological } \\
\text { mechanisms involved }\end{array}$ & References \\
\hline $\begin{array}{l}\text { Post-anthesis } \\
\text { controlled soil } \\
\text { drying }\end{array}$ & $\begin{array}{c}\text { Soil water potential is kept }-15 \text { to }-20 \mathrm{kPa} \text { at } 15-20 \mathrm{~cm} \\
\text { depth from } 7 \text { days after anthesis to maturity }\end{array}$ & $\begin{array}{l}\text { Enhancing remobilization of NSC from } \\
\text { stems to grains by regulating enzymes in } \\
\text { the stems and grains }\end{array}$ & {$[19,61-64]$} \\
\hline $\begin{array}{l}\text { Alternate wetting } \\
\text { and moderate soil } \\
\text { drying during the } \\
\text { growing season }\end{array}$ & $\begin{array}{l}\text { Except at the stages of re-greening, meiosis and flowering, } \\
\text { at which plants are well-watered, fields are not irrigated } \\
\text { until soil water potential reached }-10 \text { to }-15 \mathrm{kPa} \text { at } \\
15-20 \mathrm{~cm} \text { depth }\end{array}$ & $\begin{array}{l}\text { Reducing redundant vegetative growth } \\
\text { at early and mid growth stages and } \\
\text { enhancing grain fill through balance } \\
\text { among hormones during the grain } \\
\text { filling period }\end{array}$ & {$[19,65-67]$} \\
\hline $\begin{array}{l}\text { Non-flooded straw } \\
\text { mulching } \\
\text { cultivation }\end{array}$ & $\begin{array}{l}\text { Wheat or rice straw is used to cover the soil. Fields are only } \\
\text { flooded during the re-greening. Water }\left(380-440 \mathrm{~kL} \cdot \mathrm{hm}^{-2}\right) \\
\text { is applied to plants at each stage of mid-tillering, booting, } \\
\text { flowering, and early grain fill if soil water potential reached } \\
\qquad-25 \mathrm{kPa} \text { at } 15-20 \mathrm{~cm} \text { depth }\end{array}$ & $\begin{array}{l}\text { Improving canopy structure, } \\
\text { maintaining high root activity and } \\
\text { enhancing sink activity during the } \\
\text { grain filling period }\end{array}$ & {$[19,68-71]$} \\
\hline
\end{tabular}


season and non-flooded straw mulching cultivation, could substantially enhance WUE and maintain, or even increase, grain yield of rice, mainly via enhanced remobilization of stored carbon from vegetative tissues to grains and improved HI. It is recommended that farmers adopt the technique of post-anthesis controlled soil drying, if they have used excessive $\mathrm{N}$ fertilizer or are growing a hybrid rice cultivar which is too vigorous. It would be a good option for farmers to adopt non-flooded straw mulching cultivation in the areas where rice-wheat rotations are the main cropping system or where water is scarce but temperature is favorable to rice growth. The technique of alternate wetting and moderate soil drying irrigation could be used for all the irrigated lowland system.

Further research is needed to understand: (1) the mechanisms underlying $\mathrm{N}$ uptake, assimilation and remobilization in N-efficient cultivars, (2) factors both intrinsic and extrinsic to spikelets that may regulate grain fill and environmental factors that affect grain filling rates in inferior spikelets, and (3) synergistic interaction between water and nitrogen on the crop and in the soil, and the mechanisms underlying resource use efficiency in high-yielding rice.

Acknowledgements The National Natural Science Foundation of China (31461143015; 31271641, 31471438, 91317307), the National Key Technology Support Program of China (2011BAD16B14, 2012BAD04B08, 2014AA10A605), the Priority Academic Program Development of Jiangsu Higher Education Institutions, Jiangsu Creation Program for Post-graduation Students (KYZZ 0364) are thanked for their financial support.

Compliance with ethics guidelines Jianchang Yang declares that there is no conflict of interest or financial conflicts to disclose.

This article is a review and does not contain any studies with human or animal subjects performed by the author.

\section{References}

1. Fageria N K. Yield physiology of rice. Journal of Plant Nutrition, 2007, 30(6): 843-879

2. Peng S B, Tang Q Y, Zou Y B. Current status and challenges of rice production in China. Plant Production Science, 2009, 12(1): 3-8

3. Peng S, Buresh R J, Huang J, Zhong X, Zou Y, Yang J, Wang G, Liu Y, Hu R, Tang Q, Cui K, Zhang F, Dobermann A. Improving nitrogen fertilization in rice by site-specific $\mathrm{N}$ management. A review. Agronomy for Sustainable Development, 2010, 30(3): 649656

4. Food and Agricultural Organization of United Nations (FAO). FAOSTAT Databases. Agricultural Production. Rome: FAO, 2014

5. Zhang F, Chen X, Vitousek P. Chinese agriculture: an experiment for the world. Nature, 2013, 497(7447): 33-35

6. Xue Y G, Duan H, Liu L J, Wang Z Q, Yang J C, Zhang J H. An improved crop management increases grain yield and nitrogen and water use efficiency in rice. Crop Science, 2013, 53(1): 271-284

7. Zhang F S, Fan M S. Basic research for high-yielding cultivation and high use efficiency of resources in main food crops. Beijing: China Agriculture Press, 2013 (in Chinese)

8. Guo J H, Liu X J, Zhang Y, Shen J L, Han W X, Zhang W F, Christie P, Goulding K W T, Vitousek P M, Zhang F S. Significant acidification in major Chinese croplands. Science, 2010, 327(5968): $1008-1010$

9. Chen X, Cui Z, Fan M, Vitousek P, Zhao M, Ma W, Wang Z, Zhang W, Yan X, Yang J, Deng X, Gao Q, Zhang Q, Guo S, Ren J, Li S, Ye Y, Wang Z, Huang J, Tang Q, Sun Y, Peng X, Zhang J, He M, Zhu Y, Xue J, Wang G, Wu L, An N, Wu L, Ma L, Zhang W, Zhang F. Producing more grain with lower environmental costs. Nature, 2014, 514(7523): 486-489

10. Katsura K, Maeda S, Horie T, Shiraiwa T. Analysis of yield attributes and crop physiological traits of Liangyoupeijiu, a hybrid rice recently bred in China. Field Crops Research, 2007, 103(3): 170-177

11. Normile D. Agricultural research. Reinventing rice to feed the world. Science, 2008, 321(5887): 330-333

12. Li B G, Peng S Q. Report on agricultural water use during 1998-2007 in China. Beijing: China Agriculture Press, 2009 (in Chinese)

13. Qin J, Hu F, Zhang B, Wei Z, Li H. Role of straw mulching in noncontinuously flooded rice cultivation. Agricultural Water Management, 2006, 83(3): 252-260

14. Lu X, Wu L, Pang L, Li Y, Wu J, Shi C, Zhang F. Effects of plastic film mulching cultivation under non-flooded condition on rice quality. Journal of the Science of Food and Agriculture, 2007, 87(2): 334-339

15. Zheng J, Li Y G, Han Z Z. Sino-US irrigation water use efficiencies of main crops. Transactions of the Chinese Society of Agriculture Engineering, 2008, 24(11): 46-50 (in Chinese)

16. Cassman K G. Ecological intensification of cereal production systems: yield potential, soil quality, and precision agriculture. Proceedings of the National Academy of Sciences of the United States of America, 1999, 96(11): 5952-5959

17. Cassman K G, Dobermann A, Walters D T. Agroecosystems, nitrogen-use efficiency, and nitrogen management. Ambio, 2002, 31 (2): 132-140

18. Yoshida S. Physiological aspects of grain yield. Annual Review of Plant Physiology, 1972, 23(1): 437-464

19. Yang J, Zhang J. Grain filling of cereals under soil drying. The New Phytologist, 2006, 169(2): 223-236

20. Peng S, Huang J, Zhong X, Yang J, Wang G, Zou Y, Zhang F, Zhu Q, Buresh R, Witt C. Challenge and opportunity in improving fertilizer-nitrogen use efficiency of irrigated rice in China. Agricultural Sciences in China, 2002, 1(7): 776-785

21. Liu L J, Wang K J, Bian J L, Xiong Y W, Chen L, Wang Z Q, Yang J C. Differences in yield response to nitrogen fertilizer among rice cultivars and their relationship with root morphology and physiology. Acta Agronomica Sinica, 2014, 40(11): 1999-2007

22. Fan M M. Variations of nitrogen use efficiency among rice varieties and their physiological mechanism. Dissertation for the Master Degree. Yangzhou: Yangzhou University, 2012 (in Chinese)

23. Ju C, Buresh R J, Wang Z, Zhang H, Liu L, Yang J, Zhang J. Root and shoot traits for rice varieties with higher grain yield and higher nitrogen use efficiency at lower nitrogen rates application. Field 
Crops Research, 2015, 175: 47-55

24. Kato T, Takeda K. Associations among characters related to yield sink capacity in space-planted rice. Crop Science, 1996, 36(5): 1135-1139

25. Kato T, Shinmura D, Taniguchi A. Activities of enzymes for sucrose-starch conversion in developing endosperm of rice and their association with grain filling in extra-heavy panicle types. Plant Production Science, 2007, 10(4): 442-450

26. Yang J, Zhang J. Grain-filling problem in 'super' rice. Journal of Experimental Botany, 2010, 61(1): 1-5

27. Peng S, Cassman K G, Virmani S S, Sheehy J, Khush G S. Yield potential trends of tropical since the release of IR8 and its challenge of increasing rice yield potential. Crop Science, 1999, 39(6): 1552 1559

28. Cheng S H, Zhuang J Y, Fan Y Y, Du J H, Cao L Y. Progress in research and development on hybrid rice: a super-domesticate in China. Annals of Botany, 2007, 100(5): 959-966

29. Peng S, Khush G S, Virk P, Tang Q, Zou Y. Progress in ideotype breeding to increase rice yield potential. Field Crops Research, 2008, 108(1): 32-38

30. Yang J, Peng S, Zhang Z, Wang Z, Visperas R M, Zhu Q. Grain and dry matter yields and partitioning of assimilates in japonica/indica hybrids. Crop Science, 2002, 42(3): 766-772

31. Ao H, Wang S, Zou Y, Peng S, Tang Q, Fang Y, Chen Y, Xiong C, Xiao A. Study on yield stability and dry matter characteristics of super hybrid rice. Scientia Agricultura Sinica, 2008, 41(7): 19271936 (in Chinese)

32. Mohapatra P K, Patel R, Sahu S K. Time of flowering affects grain quality and spikelet partitioning within the rice panicle. Australian Journal of Plant Physiology, 1993, 20(2): 231-242

33. Yang J, Peng S, Visperas R M, Sanico A L, Zhu Q, Gu S. Grain filling pattern and cytokinin content in the grains and roots of rice plants. Plant Growth Regulation, 2000, 30(3): 261-270

34. Yuan L P. Recent progress in breeding super hybrid rice in China. In: Virmani S S, Mao C X, Harby B. eds. Hybrid rice for food security, poverty alleviation, and environmental protection. Philippines: International Rice research Institute, 2003

35. Yang J. Mechanism and regulation in the filling of inferior spikelets of rice. Acta Agronomica Sinica, 2010, 36(12): 2011-2019 (in Chinese)

36. Fu J. Yield formation physiology and cultivation regulation in super rice. Dissertation for the Doctoral Degree. Yangzhou: Yangzhou University, 2012

37. Nakamura Y, Yuki K. Changes in enzyme activities associated with carbohydrate metabolism during development of rice endosperm. Plant Science, 1992, 82(1): 15-20

38. Fu J, Huang H, Wang Z, Yang J, Zhang J. Pre-anthesis nonstructural carbohydrate reserve in the stem enhances the sink strength of inferior spikelets during grain filling of rice. Field Crops Research, 2011, 123(2): 170-182

39. Yang J, Zhang J, Huang Z, Wang Z, Zhu Q, Liu L. Correlation of cytokinin levels in the endosperms and roots with cell number and cell division activity during endosperm development in rice. Annals of Botany, 2002, 90(3): 369-377

40. Yang J, Zhang J, Wang Z, Zhu Q. Hormones in the grains in relation to sink strength and postanthesis development of spikelets in rice.
Plant Growth Regulation, 2003, 41(3): 185-195

41. Yang J, Zhang J, Liu K, Wang Z, Liu L. Abscisic acid and ethylene interact in wheat grains in response to soil drying during grain filling. The New Phytologist, 2006, 171(2): 293-303

42. Yang J, Zhang J, Wang Z, Liu K, Wang P. Post-anthesis development of inferior and superior spikelets in rice in relation to abscisic acid and ethylene. Journal of Experimental Botany, 2006, 57(1): 149-160

43. Zhang Z, Chu G, Liu L, Wang Z, Wang X, Zhang H, Yang J, Zhang J. Mid-season nitrogen application strategies for rice varieties differing in panicle size. Field Crops Research, 2013, 150(1): 9-18

44. Zhang H, Li H, Yuan L, Wang Z, Yang J, Zhang J. Post-anthesis alternate wetting and moderate soil drying enhances activities of key enzymes in sucrose-to-starch conversion in inferior spikelets of rice. Journal of Experimental Botany, 2012, 63(1): 215-227

45. Chen T, Xu Y, Wang J, Wang Z, Yang J, Zhang J. Polyamines and ethylene interact in rice grains in response to soil drying during grain filling. Journal of Experimental Botany, 2013, 64(8): 2523-2538

46. Wang Z, Xu Y, Chen T, Zhang H, Yang J, Zhang J. Abscisic acid and the key enzymes and genes in sucrose-to-starch conversion in rice spikelets in response to soil drying during grain filling. Planta, 2015, 241(5): 1091-1107

47. Bouman B A M. A conceptual framework for the improvement of crop water productivity at different spatial scales. Agricultural Systems, 2007, 93(1-3): 43-60

48. Kijne J W, Barker R, Molden D. Water productivity in agriculture: limits and opportunities for improvement. Wallingford: $C A B I$ Publishing, 2002

49. Kijne J W, Tuong T P, Bennett J, Bouman B A M, Oweis T. Ensuring food security via crop water productivity improvement. In: Background Papers - Challenge program for food and water. Colonbo: CGIAR-IWMI, 2003

50. Ehlers W, Goss M. Water dynamics in plant production. Wallingford: CABI Publishing, CAB International, 2003

51. Zhang J, Yang J. Crop yield and water use efficiency. In: Bacon M A. ed. Water use efficiency in plant biology. Oxford: Blackwell Publishing, 2004

52. Li F, Yu J, Nong M, Kang S, Zhang J. Partial root-zone irrigation enhanced soil enzyme activities and water use of maize under different ratios of inorganic to organic nitrogen fertilizers. Agricultural Water Management, 2010, 97(2): 231-239

53. Yang J, Zhang J. Crop management techniques to enhance harvest index in rice. Journal of Experimental Botany, 2010, 61(12): 31773189

54. Bueno C S, Lafarge T. Higher crop performance of rice hybrids than of elite inbreds in the tropics: 1 . Hybrids accumulate more biomass during each phenological phase. Field Crops Research, 2009, 112 (2-3): 229-237

55. Ju J, Yamamoto Y, Wang Y L, Shan Y H, Dong G C, Miyazaki A, Yoshida T. Genotypic differences in dry matter accumulation, nitrogen use efficiency and harvest index in recombinant inbred lines of rice under hydroponic culture. Plant Production Science, 2009, 12(2): 208-216

56. Yang J, Zhang J, Huang Z, Zhu Q, Wang L. Remobilization of carbon reserves is improved by controlled soil-drying during grain filling of wheat. Crop Science, 2000, 40(6): 1645-1655 
57. Zhang X Y, Chen S Y, Sun H Y, Pei D, Wang Y M. Dry matter, harvest index, grain yield and water use efficiency as affected by water supply in winter wheat. Irrigation Science, 2008, 27(1): 1-10

58. Guo Q F, Wang Q C, Wang L M. Maize production in China. Shanghai: Shanghai Science \& Technology Press, 2004 (in Chinese)

59. D'Andrea K E, Otegui M E, de la Vega A J. Multi-attribute responses of maize inbred lines across managed environments. Euphytica, 2008, 162(3): 381-394

60. Zhang H, Chen T T, Liu L J, Wang Z Q, Yang J C, Zhang J H. Performance in grain yield and physiological traits of rice in the Yangtze River Basin of China during the last 60 yr. Journal of Integrative Agriculture, 2013, 12(1): 57-66

61. Yang J, Zhang J, Liu L, Wang Z, Zhu Q. Carbon remobilization and grain filling in japonica/indica hybrid rice subjected to post-anthesis water deficits. Agronomy Journal, 2002, 94(1): 102-109

62. Yang J, Zhang J, Wang Z, Liu L, Zhu Q. Postanthesis water deficits enhance grain filling in two-line hybrid rice. Crop Science, 2003, 43 (6): 2099-2108

63. Yang J, Zhang J, Wang Z, Zhu Q. Activities of starch hydrolytic enzymes and sucrose-phosphate synthase in the stems of rice subjected to water stress during grain filling. Journal of Experimental Botany, 2001, 52(364): 2169-2179

64. Yang J, Zhang J, Wang Z, Zhu Q, Wang W. Remobilization of carbon reserves in response to water deficit during grain filling of rice. Field Crops Research, 2001, 71(1): 47-55
65. Yang J, Liu K, Wang Z, Du Y, Zhang J. Water-saving and highyielding irrigation for lowland rice by controlling limiting values of soil water potential. Journal of Integrative Plant Biology, 2007, 49 (10): 1445-1454

66. Zhang H, Xue Y, Wang Z, Yang J, Zhang J. An alternate wetting and moderate soil drying regime improves root and shoot growth in Rice. Crop Science, 2009, 49(6): 2246-2260

67. Zhang $\mathrm{H}$, Chen $\mathrm{T}$, Wang Z, Yang J, Zhang J. Involvement of cytokinins in the grain filling of rice under alternate wetting and drying irrigation. Journal of Experimental Botany, 2010, 61(13): 3719-3733

68. Zhang Z, Zhang S, Yang J, Zhang J. Yield, grain quality and water use efficiency of rice under non-flooded mulching cultivation. Field Crops Research, 2008, 108(1): 71-81

69. Xu G, Zhang J, Lam H, Wang Z, Yang J. Hormonal changes are related to poor grain filling in the inferior spikelets of rice cultivated under non-flooded and mulched condition. Field Crops Research, 2007, 101(1): 53-61

70. Xu G, Zhang Z, Zhang J, Yang J. Much improved water use efficiency of rice under non-flooded mulching cultivation. Journal of Integrative Plant Biology, 2007, 49(10): 1527-1534

71. Zhang Z, Xue Y, Wang Z, Yang J, Zhang J. The relationship of grain filling with abscisic acid and ethylene under non-flooded mulching cultivation. Journal of Agricultural Science, 2009, 147(2): 423436 